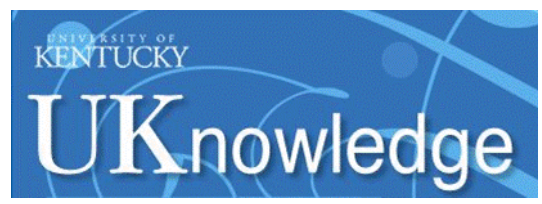

University of Kentucky

UKnowledge

$9-2015$

\title{
Ebony and Ivory? Interracial Dating Intentions and Behaviors of Disadvantaged African American Women in Kentucky
}

\author{
David J. Luke \\ University of Kentucky, david.luke@uky.edu \\ Carrie B. Oser \\ University of Kentucky, carrie.oser@uky.edu
}

Follow this and additional works at: https://uknowledge.uky.edu/sociology_facpub

Part of the Family, Life Course, and Society Commons, Gender and Sexuality Commons, and the Race and Ethnicity Commons

Right click to open a feedback form in a new tab to let us know how this document benefits you.

\section{Repository Citation}

Luke, David J. and Oser, Carrie B., "Ebony and Ivory? Interracial Dating Intentions and Behaviors of Disadvantaged African American Women in Kentucky" (2015). Sociology Faculty Publications. 16. https://uknowledge.uky.edu/sociology_facpub/16

This Article is brought to you for free and open access by the Sociology at UKnowledge. It has been accepted for inclusion in Sociology Faculty Publications by an authorized administrator of UKnowledge. For more information, please contact UKnowledge@lsv.uky.edu. 
Ebony and Ivory? Interracial Dating Intentions and Behaviors of Disadvantaged African American Women in Kentucky

Digital Object Identifier (DOI)

https://doi.org/10.1016/j.ssresearch.2015.06.016

Notes/Citation Information

Published in Social Science Research, v. 53, p. 338-350.

Copyright @ 2015 Elsevier Inc. All rights reserved.

This manuscript version is made available under the CC-BY-NC-ND 4.0 license https://creativecommons.org/licenses/by-nc-nd/4.0/.

The document available for download is the author's post-peer-review final draft of the article. 


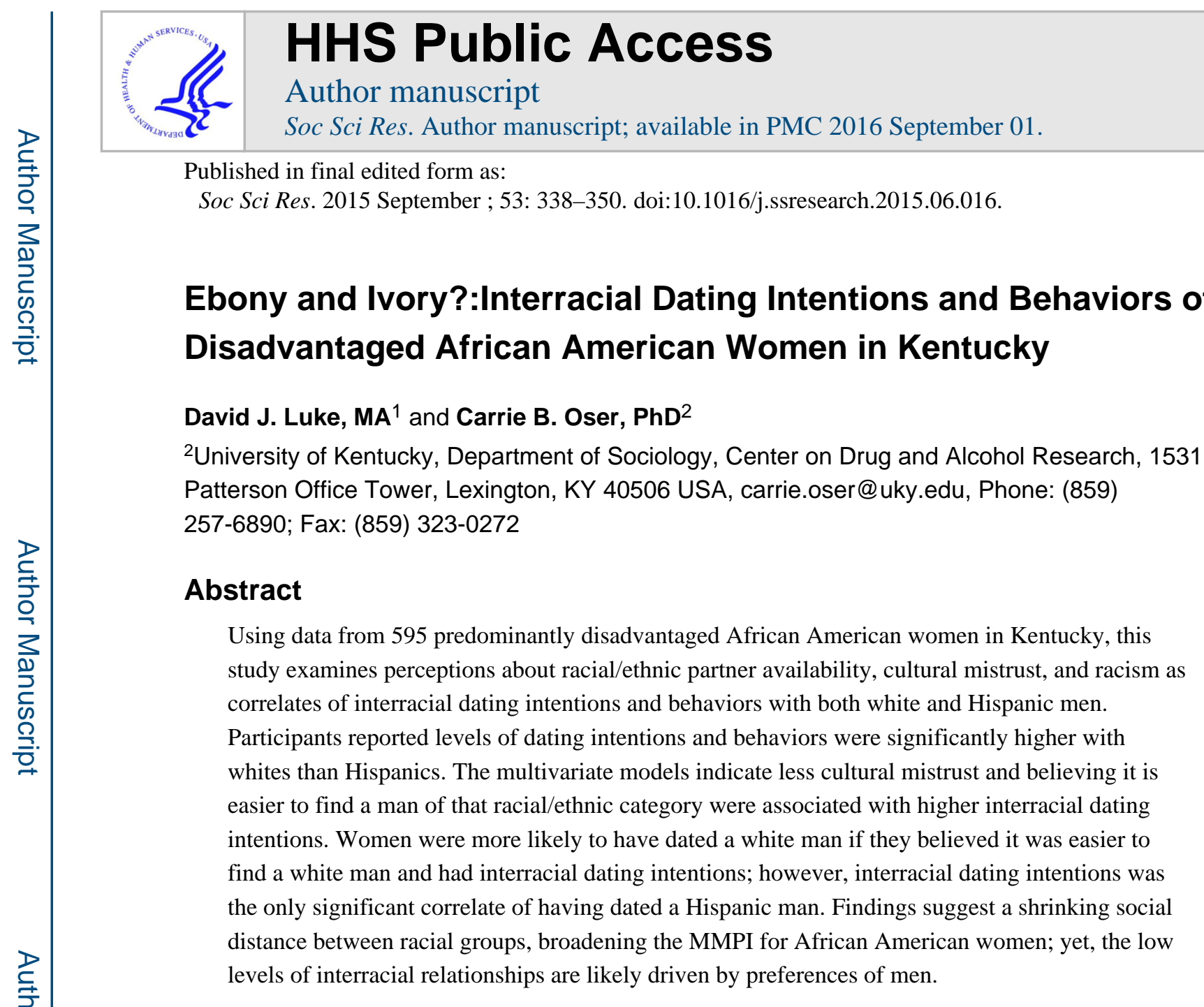

\section{Keywords}

Interracial Relationships; African American Women; Male Marriageable Pool Index; Perceptions about Partner Availability; Cultural Mistrust; Racism

\section{Introduction}

Rates of interracial marriage and of willingness to marry interracially, although rising, are still quite low (Bratter \& Eschbach, 2006; Childs, 2005; Lewis \& Ford-Robertson, 2010), and African American women are less likely to marry than women of other racial groups (U. S. Census Bureau, 2011). Marriage is often preceded by dating; thus, it is important to examine interracial dating intentions and behaviors, and the complicating factor of class distinctions. Pairing intentions and behaviors is important, as prior research would suggest that intentions are more prevalent than actual behaviors (Bonilla-Silva, 2001). Additionally, with marriage rates in general declining and cohabitation and other living arrangements on the rise (U.S. Census Bureau, 2005; U.S. Census Bureau, 2011), the dearth of research on non-matrimonial interracial romantic relationships is problematic. Limited scholarly work

\footnotetext{
${ }^{1}$ Corresponding Author. University of Kentucky, Department of Sociology, 1515 Patterson Office Tower, Lexington, KY 40506 USA, david.luke@uky.edu, Phone (cell): (616) 617-6338; Fax: (859) 323-0272.
} 
has focused on the correlates of or experiences with intimate partner relationships among economically disadvantaged African American women despite their reduced presence in the dating/marriage pools.

Often, research suggests the gendered pattern of African American and white interracial marriage (with lower levels of intermarriage among African American women and white men) indicates bias on the part of black women, but little recent research has empirically examined this issue of interracial dating intentions and behaviors, especially from the perspective of the African American woman (Childs, 2005). This study does, and is guided by William Julius Wilson's (1987) concept of the Male Marriageable Pool Index (MMPI). The MMPI is the sex ratio, or the number of eligible males per 100 females, within a same race and age group. Recently analyzed 2010 Census data notes that the sex ratio in the 2554 prime-age group is more unbalanced for African Americans than any other racial group, with 83 men per 100 women for African Americans as compared to 99 men per 100 women for whites (Wolfers, Leonhardt, \& Quealy, 2015). The current study is unique in the inclusion of items inspired by the MMPI which measure African American women's perceptions about the availability of partners who are African American, white, and Hispanic. From a MMPI framework, African American women's assessment of the availability of same-race partners may influence their interracial dating intentions and behaviors.

Therefore, the goal of this study is to examine how perceptions about racial/ethnic partner availability, cultural mistrust, and experiences of racist events contribute to the interracial dating intentions and behaviors with both white and Hispanic men using a sample of socioeconomically disadvantaged African American women in Kentucky. This novel study is significant in that it explores the relationship intentions and behaviors of a uniquely marginalized and often-overlooked group, shifts the focus from marriage to romantic relationships, and challenges the traditional view that the biases of African American women drive their aversion to interracial relationships.

\subsection{African American Women's Relationship Trends}

Interracial marriage was not made legal until June 12, 1967 in the Supreme Court decision in the case of Loving v. Commonwealth of Virginia (Bratter \& Eschbach, 2006; Jacobson \& Johnson, 2006). Thus, the first major study on interracial marriage was completed in the 1970s by David Heer, and revealed a 26\% increase in the number of African American and white interracial marriages between 1960 and 1970 (Heer, 1974; Lewis \& Ford-Robertson, 2010). Nevertheless, African American women in general have historically been unlikely to marry, and there has been a dramatic decline in their marriage rate between 1970 and 1990 (Crowder \& Tolnay, 2000; Harris \& Ono, 2005; Raley \& Sullivan, 2010). Even the most recent U.S. Census Bureau $(2005,2011)$ data estimates a decline in the percentage of married African American women between 2005 (29.19\%) to 2010 (26.93\%).

It is not just marriage, though, as research has demonstrated that college-educated African American women experience lower levels of marriage, but also lower levels of romantic partnership and voluntary sexual activity compared to white or Hispanic women (Clarke, 2011). The picture painted is one in which relatively privileged African American women 
are deprived of marriage opportunities, but also of romantic love altogether when compared to other racial groups (Clarke, 2011). For purposes of childbearing, Clarke refers to unmarried parenting as "the only game in town" (Clarke, 2011:100). This is not simply a numbers game; critiquing those who might use indices like the MMPI exclusively as an explanation of low marriage rates among degreed African American women, Clarke notes:

"In short, sex ratio explanations for race, class, or gender inequalities of love only become meaningful amid inequality-generating processes that ensure that racial (and class) boundaries around dating populations are maintained (Clarke, 2011: 281)."

Viewing the marginalization of college-educated African American women (who are privileged compared to the Kentucky women in this study) in the "love" market leaves dim prospects for more disadvantaged African American women.

\subsection{Perceptions about the Availability of Partners and Interracial Dating}

The current study is guided by the work of William Julius Wilson, who conceptualized the Male Marriageable Pool Index (MMPI) (Wilson, 1987). This study does not test the MMPI concept, but rather, uses it as an interpretive and theoretical framework. Wilson noted that male joblessness, mortality, and incarceration in the African American community reduced the number of eligible (or marriageable) African American men (Wilson, 1987). Wilson calculated MMPI values for different age and racial groups, since individuals generally tend to marry someone of the same race who is around the same age (Wilson, 1987). He noted that these values were different across racial groups such that African American women had a considerably smaller pool of potential partners when compared to white women (Wilson, 1987). Beliefs regarding partner availability are important in shaping intentions and behavior from a MMPI framework. Specifically, African American women who perceive that it is difficult to find an eligible African American man or that it is easier to find an eligible white or Hispanic man may be more likely to intend to date interracially. Likewise, African American women who have these perceptions about the limited availability of same-race partners and the greater availability of partners outside their race may be more likely to engage in interracial relationships. This study includes three items inspired by the MMPI to measure perceptions about the availability of African American, white, and Hispanic male partners. Moreover, this study examines the association between the items measuring perceptions about partner availability and interracial relationship intentions and behaviors of disadvantaged African American women in Kentucky. Interracial relationship intentions are likely a strong predictor of dating someone of another race (Ajzen, 1991).

Wilson's MMPI has been praised for examining the broad social and economic elements related to the marriage squeeze for African American women, rather than simply the demographic aspects of race and age; this marriage squeeze results from heterosexual women outnumbering men, and occurs sooner for African American women than whites (Bennett, Bloom, \& Craig, 1989). This is due in part to high rates of death, mass incarceration, and disproportionately high unemployment among African American men that dramatically reduce the number of eligible same-race mates (Alexander, 2010; Bennett et al., 1989; Janoski, Luke \& Oliver, 2014; Wilson, 1987). The result is a smaller 
marriageable pool of African American men for African American women. These factors discussed decades ago by Wilson (1987) still exist today and have resulted in the sex ratio being more unbalanced for African Americans than for any other racial group (US Census Bureau, 2000; Wolfers, Leonhardt, \& Quealy, 2015).

The MMPI assumes that heterosexual African American women prefer African American male partners, and this has been supported by previous research (Harris \& Ono, 2005; Laumann \& Youm, 1999; Staples, 1981). On the other hand, African American women's preferences are not the only ones involved in mate selection - the potential partners' preferences are also a factor. Potential partners may exclude African American women from the dating pool based on their race. Prior research examining the preferences of white internet daters has revealed that race or ethnicity is one of the top criteria they use when considering partners to date (Feliciano, Robnett \& Komaie, 2009). In fact, white men preferred not to date African American women at a rate of over $90 \%$ (Feliciano et al., 2009). This is evidence of "black exceptionalism," or the willingness to date outside of one's race as long as the potential partner is not African American (Kroeger \& Williams, 2011). This trend suggests a shift from a white/black divide to a black/nonblack divide, which could be looked at as an extension of the "one-drop rule" (excluding people who have even any trace of African ancestry) (Kroeger \& Williams, 2011). Other studies also show a lower tolerance of intermarriage with African Americans than with other racial groups (Dougherty \& Huyser 2008; Feliciano et al., 2009; Golebiowska, 2007; Jacobson \& Johnson, 2006; Quillian \& Campbell, 2003). The low rates of intermarriage among African Americans and the evidence of a black/nonblack divide suggest African American women's interracial relationship behaviors and intentions need to be explored with both whites and Hispanics.

Previous studies have shown a higher likelihood of intermarriage between African Americans and Hispanic individuals than between African Americans and whites (Qian \& Lichter, 2001). Since both of these groups are marginalized racial minorities in the U.S., it is possible that this common status makes cultivation of interracial romance more likely between members of these groups. In addition, Hispanic individuals are more likely than whites or African Americans to marry interracially, so it is possible that the preferences of Hispanic males are less of a barrier for African American women with intentions to date them, due to the lessened stigma of interracial marriage in their communities (Heaton \& Jacobson, 2000). As such, it is important to examine African American women's perceptions about the availability of Hispanic men as they may be associated with a greater likelihood of both intending to date a Hispanic man and engaging in a relationship with a Hispanic man.

\subsection{The Role of Cultural Mistrust and Racism in Interracial Dating}

Some research suggests that African American women are among the strongest opponents of interracial relationships (Harris \& Ono, 2005; Laumann \& Youm, 1999; Staples, 1981). Again, more current research is needed on African American women's views on interracial dating. However, it is reasonable to conclude that African American women's preference to date African American men could be attributed to their experiences of discrimination and racism, which may result in sentiments of cultural mistrust (Childs, 2005; Feagin, Vera \& Batur, 2000; Terrell \& Terrell, 1996). For example, victims of racism may choose avoiding 
interracial contact as a coping mechanism and to prevent future victimization; thereby, decreasing the likelihood that an African American woman would seek a partner outside of her race (Barnes \& Lightsey Jr., 2005). Beyond personal experiences, knowledge of negative experiences of friends and family members as well as the history of antiblack racism and patriarchy in the United States may also lead to a decision to avoid interracial contact (Collins 2001; Feagin 2014).

These instances of racism and the resulting avoidance are intricately connected to cultural mistrust, as the avoidance of interracial interaction could reasonably be viewed as indicative of cultural mistrust. Mistrust can be reasonably linked to patterns of relationship preference. A study of African American and whites' internet dating preferences revealed African American's hesitation to date whites, even when controlling for demographic variables (Yancey, 2009), possibly indicating the impact of cultural mistrust on romantic relationship patterns. Additionally, African American women often see African American men's choices to partner with white women as betrayal and rejection of African American women as a group, which could fuel their opposition to interracial relationships (Childs, 2005). The increase in interracial marriage between African American men and women of other races (Crowder \& Tolnay, 2000) further depletes the "male marriageable pool" for African American women (Wilson, 1987). This may also provide the foundation for higher levels of cultural mistrust among African American women.

\subsection{Socio-demographic Factors are Associated with Interracial Dating}

There are a number of socio-demographic factors associated with interracial marriage including being younger, more educated, and wealthier (Golebiowska, 2007; Johnson \& Jacobson, 2005). Less educated and economically disadvantaged African American women are particularly unlikely to marry at all, let alone marry interracially (Bennett et al., 1989; Heaton \& Jacobson, 2000). This may be partially explained by these women being more likely to have outof-wedlock children, making them less desirable as a potential mate (Bennett et al., 1989).

African American women's skin color could also be a factor in interracial dating. This factor is likely more pertinent to the preferences of the potential partners of African American women. Lighter skin tone, which fits more closely with the socially constructed European American standard of beauty, is rated as more attractive, regardless of one's race (Bond \& Cash, 1992; Maddox, 2004). As lighter skinned African American women are deemed more attractive (Russell, Wilson \& Hall, 1993), they may be more likely to be pursued by white or Hispanic men and thus be more likely to interracially date.

African American women have less power in negotiating the terms of their romantic relationships because there are fewer African American men, and they may be seen as a commodity (Newsome \& Airhihenbuwa, 2013; Thomas \& Thomas, 1999; Wolfers, Leonhardt, \& Quealy, 2015). African American women's lack of bargaining power may be magnified when women have multiple disadvantaged statuses, such as having a history of drug use and/or incarceration (Oser et al., 2014; Staton-Tindall et al., 2007). Recently, scholars highlight the importance and need for more within-group research, especially among disadvantaged minority populations (Knight, Roose, \& Umaña-Taylor, 2009). Thus, 
it is imperative to examine African American women with multiple disadvantaged statuses and their perceptions of the availability of partners within and outside their race. Women who may lack the bargaining power to be selective and believe it is difficult to find an eligible African American man may broaden their base of potential mates by looking outside of their race.

\subsection{The Current Study}

Clearly, there is a constellation of factors that contribute to African American women's interracial relationship intentions and behaviors. This topic is important to examine because there is a clear juxtaposition faced by African American women. While racism and cultural mistrust may encourage African American women to only consider dating African American men, the limited pool of eligible African American male partners may dictate that African American women look outside their racial group for potential partners. However, African American women who are open to interracial dating may be excluded from the dating pool by potential partners due to their race, resulting in African American women's interracial behaviors lagging behind their interracial dating intentions. This study offers a unique opportunity to examine these issues from the perspective of the economically disadvantaged African American woman, who are the least likely to interracially marry (Bennett et al., 1989; Crowder \& Tolnay, 2000; Heaton \& Jacobson, 2000). Specifically, this study uses data from economically disadvantaged African American women to explore how perceptions about racial/ethnic partner availability, cultural mistrust, and experiences of racism are associated with both interracial dating intentions and behaviors. While this study is not a direct test of the MMPI, it does provide a useful framework for explaining African American women's consideration and participation in interracial relationships with both white and Hispanic men when faced with a depleted male marriageable pool due to documented higher rates of unemployment, incarceration, mortality, and interracial marriage of African American men (Alexander, 2010; Janoski, Luke \& Oliver, 2014; Wilson, 1987).

\section{Methods}

\subsection{Sample}

The current study analyzed data from the Black Women in the Study of Epidemics (BWISE) project, a study examining health disparities and health services utilization. The BWISE project includes data collected between 2008 and 2011 from 643 African American women in Kentucky, with the aim to sample equal proportions of women who were incarcerated at baseline, on probation, and not involved in the criminal justice system. In addition, participants who self-reported illicit drug use were intentionally oversampled using stratified sampling procedures. Eligibility criteria for all participants included: (a) selfidentification as an African American woman; (b) being at least 18 years of age; and (c) willingness to participate.

The recruitment strategy varied for the three groups. For the prison sample, all African American women eligible for community reentry within the next 60 days were invited to participate in the study via an information session. Interviews were conducted in a private room in the prison. For the probation sample, African American women were recruited from 
seven Probation District offices on report days by project staff and by flyers. For community participants, recruitment efforts were focused on the zip codes identified as having large African American populations based on census data, and recruiting methods included flyers and newspaper advertisements. The additional eligibility criteria for the community sample included that the person could not currently be involved in the criminal justice system (e.g., on probation, parole, or have pending charges). For the probation and community samples, interviews were conducted in private locations such as a room in a public library or an office on a university campus.

Trained African American female interviewers obtained informed consent and used laptops with Computer Assisted Personal Interviewing (CAPI) software to interview the participants. Institutional Review Board approval was received for the study and participants were compensated $\$ 20$ for participating in the interview. Due to the regional nature of the sample as described and the intentional oversampling of drug users and women involved in the criminal justice system, this sample is not representative of all African American women in the U.S. However, this study still makes a significant contribution to the literature because it is conservative in nature. Rather than examining interracial dating among middle-class or more upwardly mobile African American women, it is examining the dating behaviors and intentions of a sample of African American women who are more disadvantaged and may have less choice in partner selection.

The original B-WISE sample had 643 participants; however, only 595 participants were included in these analyses examining the significant correlates of both interracial dating intentions and behaviors. Specifically, $42(6.53 \%)$ cases were excluded because they identified as homosexual and the dependent variables of interest refer to heterosexual relationships. Another six $(0.93 \%)$ respondents did not provide their age, so those respondents were omitted.

\subsection{Measures}

Four dichotomous dependent variables were of interest in this study. Participants were asked: "Would you ever date someone who is white?", "Would you ever date someone who is Hispanic?", "Have you ever dated someone who is white?", and "Have you ever dated someone who is Hispanic?". Responses for each of the four dependent variables were coded where $1=y e s$ and $0=n o$.

Two control variables, past year drug use and criminal justice status, were included in the multivariate models as they were part of the sampling strategy. Drug use in the past year, or the year prior to incarceration for the prison sample, was a dichotomous variable $(0=n o ; 1$ $=$ yes). . Criminal justice status measured if the participant was recruited from prison, a probation office, or the community. A prison dummy variable was created $(0=$ not recruited in prison; $1=$ recruited in prison $)$ and a probation dummy variable was created $(0=n o t$ recruited while on probation; $1=$ recruited while on probation). The community sample was the reference category.

The sociodemographic variables of age, household income, and education were also included the analyses. Age and education were continuous variables measured in number of 
years. Household income was measured in income categories; however, for use in this analysis, each response was assigned the middle dollar value (in tens of thousands) of the range they selected. The top value of " $\$ 75,000$ or more" was conservatively coded to 7.5 . In addition, respondents self-described skin tones were recoded as either "very dark," "dark," "medium," "light," or "very light." One dichotomous variable was created to measure light skin tone $(0=$ medium, dark, or very dark skin tone $; 1=$ light or very light skin tone $)$.

To measure experiences of racism over one's lifetime, the Schedule of Racist Events (SRE) was employed (Landrine \& Klonoff, 1996). There were 17 items in the SRE all pertaining to whether respondents experienced a series of events, "because you are black". Examples included mistreatment from friends, coworkers, or institutions because you were black, being suspected of doing something wrong because you were black, or being called a racist name. The SRE was measured on a 6-point Likert scale, with response options of "never", "once in a while", "sometimes", "a lot", "most of the time", and "almost all of the time". Responses to all items in the scale were summed, so higher values in the SRE indicate more racist life experiences. This scale was highly reliable $(a=0.93)$ and ranged from 17 to 96.

To assess mistrust of whites by African Americans, the 14-item Cultural Mistrust Inventory (CMI; Terrell \& Terrell, 1996) was also used. Questions for this scale were statements, and response options came in the form of a seven-point Likert scale measuring the extent to which respondents agreed or disagreed with the statements (i.e., strongly disagree, disagree, somewhat disagree, neutral, somewhat agree, agree, and strongly agree). Examples of statements include "Blacks should be suspicious of a white person who tries to be friendly," and "whites will usually keep their word" (Terrell \& Terrell, 1996). Negative items were reverse-coded. Higher scores on the CMI represented a higher level of cultural mistrust toward whites. This scale was reliable $(\alpha=0.77)$ and ranged from 18 to 98 .

Three items were created specifically for this study to measure African American women's perceptions of racial/ethnic partner availability. Participants were asked "Is it difficult to find an eligible African American man" $(0=n o ; 1=y e s)$. Participants were also asked two dichotomous questions $(0=n o ; 1=y e s)$ including: "Is it easier to find an eligible white man?" and "Is it easier to find an eligible Hispanic man?"

\subsection{Analytic Plan}

This study examines the significant correlates of both African American women's interracial dating behavioral intentions as well as actual behaviors with both white men and Hispanic men. Descriptive statistics are presented for both the independent and dependent variables. Next, two paired t-tests are conducted to identify significant differences in African American women's interracial dating intentions with white versus Hispanic men, and with dating white men as compared to Hispanic men. As the dependent variables of interest are dichotomous, multivariate logistic regression was used ${ }^{12}$. The first two sets of multivariate models examine if perceptions about partner availability, cultural mistrust, and experiences

\footnotetext{
${ }^{1}$ For both models, variance inflation factors (VIFs) were utilized to check for multicollinearity, and in both cases they revealed that multicollinearity was not a problem (all VIFs $<2.0$, results not shown).

${ }^{2}$ All data were analyzed using Stata/SE, version 12.0.
} 
of racism are significant correlates of whether an African American woman would date someone white or Hispanic, respectively. The third and fourth sets of multivariate models explore if these same independent variables are significant correlates of whether an African American woman has ever dated someone white or Hispanic, respectively. All models include socio-demographic and control variables. In each of these four sets of models, variables are introduced in a stepwise progression, adding variables categorically as follows: (1) criminal justice system status, (2) socioeconomic and sociodemographic information, (3) skin tone (4) drug use, (5) cultural mistrust and racist life events, (6) MMPI-related variables (difficult to find an African American man and easier to find a white or Hispanic man). For the sets of models identifying the interracial dating behaviors, a final step of adding interracial relationship intentions as an independent variable is also included. Odds ratios, standard errors, and likelihood ratio chi-square tests are presented for all multivariate models. Figures of predicted probabilities are included to facilitate interpretation of findings.

\section{Results}

Descriptive statistics for variables included in the multivariate models are displayed in Table 1. In this sample of African American women, interracial dating intentions varied by race/ ethnicity of the potential partner with $70 \%$ of participants responding they would date someone white but only $43 \%$ stating they would date someone Hispanic. African American women also were more likely to have dated a white man (56\%) as compared to a Hispanic man (17\%). As mentioned above, drug users were oversampled, and $61 \%$ of respondents stated they used drugs in the past year. The sample was relatively evenly divided with respect to criminal justice status, as $36 \%$ of respondents were in prison, $31 \%$ on probation, and 33\% were not involved in the criminal justice system. Regarding self-identified skin tone, $20 \%$ of respondents identified as light or very light skin tone. The respondents were about 36 years old, and had an average household income of about $\$ 17,800$. Respondents averaged approximately 12 years of education in this sample. As for their perceptions on the availability of partners, $46 \%$ of respondents reported it is difficult to find an eligible African American man, whereas $26 \%$ stated it is easier to find an eligible white man and $18 \%$ noted it is easier to find an eligible Hispanic man.

Two paired t-tests were conducted to identify if significant differences existed between African American women's intentions to date white men as compared to Hispanic men and their actual behaviors. Interestingly, paired t-tests indicated a statistically significant difference in the intentions of African American female respondents to date white men as compared to Hispanic men, with a higher preference for dating white men ( $t=12.99$; $\mathrm{p}<0.001)$. Similar to interracial relationship intentions, paired t-tests revealed that African American women were significantly more likely to have dated a white man, as compared to having dated a Hispanic man $(t=17.36 ; \mathrm{p}<0.001)$.

The series of models displayed in Table 2 report the results of the stepwise multivariate models of intentions to date white men. Model 1E revealed that on average, every unit of increase on the scale measuring cultural mistrust was associated with a decrease of $4 \%$ in the odds that the respondent holds interracial relationship intentions with white men $(p<0.001)$. The same result was duplicated in Model 1F, but additionally, respondents who perceived 
that it was easier to find an eligible white man, as compared to an African American man, were over twice as likely to be willing to date a white man, all else equal (OR: $2.06 ; p<$ $0.01)$.

Predicted probabilities for both statistically significant variables are presented in Table 3 to more fully understand the statistical associations produced in Model 1F of Table 2.

Predicted probabilities revealed that respondents who felt it was not easier to find a white man and had high cultural mistrust had the lowest predicted probability of interracial dating intentions, with a predicted probability of 0.56 . Meanwhile, respondents who reported that it was easier to find a white man and had low cultural mistrust had a predicted probability of 0.87 for willingness to date someone white.

The models in Tables 2 and 4 included the same independent variables; however, African American women's intention to date someone Hispanic was the dependent variable in all of the models in Table 4. Model $2 \mathrm{E}$ revealed that on average, every additional year of education is associated with an increase of $13 \%$ in the odds that the respondent intends to date someone Hispanic ( $\mathrm{p}<0.01$ ). Additionally, every unit of increase on the scale measuring cultural mistrust is associated with a decrease of $2 \%$ in the odds that the respondent would date a Hispanic man $(p<0.05)$. Each one unit on the scale measuring racist life events is associated with an increase of $1 \%$ in the odds that the respondent would date someone Hispanic $(\mathrm{p}<0.05)$. Racist life events failed to reach statistical significance after including perceptions about partner availability in Model 2F. Respondents with the perception that it is easier to find an eligible Hispanic man were over twice as likely to be willing to date a Hispanic man, all else equal (OR: $2.09 ; p<0.01)$.

Predicted probabilities for statistically significant variables are presented in Table 5 produced by the logistic regression of interracial dating intentions in Model $2 \mathrm{~F}$ of Table 4. Predicted probabilities revealed that respondents who felt it was not easier to find a Hispanic man and had high cultural mistrust had the lowest predicted probability of interracial dating intentions, with a predicted probability of 0.34 . Meanwhile, respondents who felt it was easier to find a Hispanic man and had low cultural mistrust had a predicted probability of 0.63 for willingness to date someone Hispanic.

The third set of logistic regression models identified the significant correlates of having dated a white man (see Table 6). Model 3F showed that, on average, being in prison in the past year was associated with an increase in the likelihood of a woman ever having dated someone white by a factor of $1.58(p<0.05)$. Age was also significant in this model, and every one-year increase in age was associated with a $2 \%$ increase in the likelihood of the respondent having ever dated a white man $(p<0.05)$. Additionally, drug use in the past year was associated with an increase of $55 \%$ in the likelihood that a woman had ever dated a white man, all else equal $(p<0.05)$. Each increase of one unit on the scale measuring cultural mistrust was associated with a decrease in the likelihood of having dated a white man by $2 \%$, while each increase of one unit on the schedule of racist life events was associated with an increase in the likelihood of having dated a white man by $2 \%$, all else equal $(p<0.05)$. Finally, perceiving that it is easier to find an eligible white man was 
associated with an increase in the likelihood of having dated a white man by a factor of 2.22 , all else equal $(p<0.001)$.

Model 3G stepped in an additional independent variable, intentions to date a white man. With the inclusion of intentions to date someone white in the model, cultural mistrust and racist life events were no longer significant correlates of having dated a white man; however, one new variable, education, reached statistical significance. Specifically, each additional year of education was associated with a decreased likelihood of having ever dated a white man by $12 \%(p<0.05)$. All of the other variables remained significant and in the same direction. Finally, and predictably, respondents claiming they would date a white man was associated with an increase by a factor of 14.54 in the likelihood that they actually have done so $(p<0.001)$.

The results displayed in Table 6 are further clarified by Table 7, which provides the predicted probabilities of having ever actually dated a white man based on education, whether the respondent claimed they would date interracially, and whether the respondent believed it was easier to find an eligible white man. The results indicate a variety of trends, with the highest predicted probability of 0.86 being for women with lower education, who believed it was easier to find an eligible white man, and stated they would date a white man. On the other end of the spectrum, the lowest predicted probability of having ever dated a white man was for women with high education who said they would not date someone white and did not believe it was easier to find an eligible white man, with a value of 0.11 .

The fourth and final set of logistic regression models identified the significant correlates having dated a Hispanic man (see Table 8). Model 4F included the same independent variables in the logistic regression model predicting intentions to date a Hispanic man (Table 6, Model 3F), and showed that, on average, being in prison in the past year was associated with an increase in the likelihood of a woman ever having dated someone Hispanic by a factor of 2.32 ( $p<0.01)$. Additionally, perceiving it is easier to find an eligible Hispanic man was associated with an increase in the likelihood of having dated a Hispanic man by a factor of 2.12, all else equal $(p<0.01)$.

Model 4G included intentions to date a Hispanic man as an independent variable in identifying the significant correlates of having dated someone Hispanic. In this model, on average, being in prison was associated with a more than doubled likelihood of having dated a Hispanic man $(O R=2.25 ; p<0.05)$. While the perception that it is easier to find an eligible Hispanic man was no longer a significant correlate in this model, predictably, a respondent claiming she would date a Hispanic man was associated with an increase by a factor of 16.29 in the likelihood that they actually dated someone Hispanic $(p<0.001)$.

The results of Model 4 in Table 8 are further clarified by Table 9, which, similar to Table 8 for white men, provides the predicted probabilities of having ever actually dated a Hispanic man based on education, whether the respondent claimed they would date interracially, and the respondent's perceptions about the availability of eligible Hispanic men. The results indicate a variety of trends, with the highest predicted probability of 0.44 being for women with lower education, who believed it was easier to find an eligible Hispanic man, and stated 
they would date a Hispanic man. On the other end of the spectrum, the lowest predicted probability of having ever dated a Hispanic man was for women with high education who said they would not date someone Hispanic and did not believe it was easier to find an eligible Hispanic man, with a value of 0.02 .

\section{Discussion}

This is the first known study to explore correlates of both the interracial dating intentions and behaviors of socioeconomically disadvantaged African American women in Kentucky. This study is important in that it sheds light on how Wilson's (1987) MMPI operates over 25 years after its origin in two ways. First, it examines the relationship between African American women's perceptions about partner availability both within and outside their racial group and interracial dating. Second, this study explores possible contradictions between African American women's interracial dating intentions and behaviors.

Since Wilson's work (1987), BLS data indicates the employment trends he identified have become exacerbated as African American men have been disproportionately impacted by the recession, and the MMPI for African American women has declined as a result, with the rise of mass incarceration of African American men further depleting the marriageable pool (Alexander, 2010; Janoski, Luke \& Oliver, 2014; Wolfers, Leonhardt, \& Quealy, 2015). Previous research suggests that historically African American women preferred racially homogeneous relationships (Harris \& Ono, 2005; Laumann \& Youm, 1999; Staples, 1981; Wilson 1987) and have been less likely to date outside their race (Feliciano et al., 2009; Harris \& Ono, 2005). However, as much of this research occurred several decades ago and does not represent the direct voice of the African American women, it is unclear if African American women's preference to date African American men still exists, especially among economically disadvantaged African American women who face a smaller pool of African American male partners and may have less social capital and bargaining power in romantic relationships. This study sheds light on the driving forces behind African American women's interracial dating experiences, to determine if they are being driven by African American women's preference to date men a specific racial/ethnic group (African American, white, and Hispanic) or if interracial dating is steered by potential partners's prefence not to date African American women.

\subsection{African American Women's Levels of Interracial Dating Intentions and Behaviors are High but Vary by Partner's Race/Ethnicity}

This study displays a uniquely high rate of interracial relationship intentions and behaviors among disadvantaged African American women, a group that has historically preferred racially homogeneous relationships (Harris \& Ono, 2005; Laumann \& Youm, 1999; Staples, 1981; Wilson 1987). However, African American women's intentions and behaviors varied by the race/ethnicity of their partner and paired t-tests revealed these differences were statistically signficant. Seventy percent of African American women said they would date someone white, but only $43 \%$ would date someone Hispanic. Additionally, African American women were significantly more likely to have dated a white man (56\%), as compared to a Hispanic man (17\%). 
The importance of these findings are three-fold. First, this leads to serious skepticism regarding widley-held perceptions of African American women's unwillingness to cross racial lines romantically. Interestingly, while a depressed MMPI would likely drive African American women to seek interracial relationships, racist life events and cultural mistrust would seem to push them in the opposite direction; this study shows that in spite of the persistence of racism and other forms of oppression, disadvantaged African American women pursue and have relationships with white and Hispanic men. Second, is important to note the statistically significant difference between interracial relationship behaviors and intentions with white men as compared to Hispanic men. There are a number of possible factors at play in this disparity. It could be an access issue, such that there is an increased social and geographic distance between African Americans and Hispanics as compared to African Americans and whites in Kentucky. Thus, Hispanic men are not seen as viable relationship options and African American women report low intentions to date Hispanic men. Alternatively, the respondents could have generally held less favorable views toward Hispanic men as partners compared to white men (Bogardus, 1933; Owen, Eisner, \& McFaul, 1981; Pagnini \& Morgan, 1990). This may be particularly important for economically disadvantaged African American women, as they may be more willing to seek out interracial partnerships with men in the most privileged racial category in the U.S. Third, potential partners' relationship preferences play a large role in interracial relationship behaviors. The opportunities for African American women to date outside their race may be restricted as they may not be sought out as potential partners. For example, the study on white internet daters noted that white men preferred not to date African Americans (Feliciano et al., 2009).

\subsection{The Role of Perceptions about the Racial Composition of the Dating Pool and Cultural Mistrust in Interracial Dating}

In general, interracial relationship intentions and behaviors were both impacted by respondents' perception that it was easier to find an eligible non-African American man. Wilson's (1987) criteria for eligibility centered around employment and financial standing; however, it is unclear whether respondents in this study used the same criteria to define whether or not a man was "eligible." Still, the belief that it was easier to find an eligible man who was white or Hispanic was significantly associated with an increased likelihood of interracial relationship intentions - women who thought it was easier to find an eligible man outside of their race were much more likely to intend to date outside of their race. A respondent's perception of low MMPI is likely to lead her to explore the possibility of interracial relationships. In the past, laws and social norms exerted strong forces against interracial relationships, but this finding suggests that these social forces may have weakened, thus allowing economically disadvantaged African American women to expand their dating pool to also include members of other racial groups.

This study revealed a negative relationship between cultural mistrust and interracial dating intentions, demonstrating that African American women with higher levels of cultural mistrust were less likely to be willing to date a white or a Hispanic man. The cultural mistrust finding supports the idea that African American women possibly possess more cultural mistrust than other populations, fueling their opposition to interracial marriage 
(Childs, 2005; Terrell \& Terrell, 1996). As a result of this cultural mistrust, these women are unlikely to pursue relationships outside of their race, and likely choose relationships with African American men or none at all. This may explain why African American women as a group are particularly unlikely to marry when compared to other race and gender groups in the United States (Banks, R. R., 2011; Bennett et al., 1989; Guzzo, K., 2006; Schneider, D., 2011).

Multivariate findings also indicated that interracial relationship intentions were the most robust correlate of interracial relationship behavior. Stated another way, African American women in this study who intended to date a white or Hispanic man were very likely to follow through on their intentions. Interestingly, increases in age were associated with an increase in having dated someone white (but not Hispanic). It could be that older individuals have spent more time being single and, facing a lower male marriageable pool of their own race, at some point looked outside their race for partnership. More educated African American women were less likely to have dated white men. The education factor could be explained in part by Historically Black Colleges and Universities (HBCUs) and the persistent segregation of educational institutions, even among institutes of higher education (Qian \& Lichter, 2007). This segregation would continue to limit the opportunities of individuals to date white men as they go through higher education, so although intentions may rise with education, opportunities for interracial relationships may still remain relatively low. In addition to these factors, residential and religious segregation persist, limiting opportunities for social contact, dating, and intermarriage between African Americans and whites (Feliciano et al., 2009; Luke, 2012; Massey \& Denton, 1993).

Finally, the controls of past year drug use and prison status were both significantly associated with having dated someone white, and prison status (but not drug use) was significantly associated with having dated a Hispanic man. There are a variety of explanations for these relationships. It is possible that these women have dated outside their race because they face a smaller pool of eligible African American men than the general population of African American women as they may be deemed "less desireable" romantic partners due to their multiple disadvantaged statuses (Oser et al., 2015; Staton-Tindall et al., 2007). Additionally, because interracial relationships are still somewhat stigmatized and are by no means normative, people who have used drugs and been imprisoned already deal with strong social stigma and may be less averse to this form of "deviant" behavior. Indeed if the self is socially constructed and based on what individuals think that others think of them, drug use and imprisonment would likely lead one to believe she is considered a deviant by society-at-large; in this situation, she may not be opposed to engaging in interracial relationships in spite of the stigma attached to interracial dating (Mead, 1934). So if fewer African American women are getting married, but their MMPI is unfavorable, perhaps already being stigmatized in other ways leads African American women with a history of drug use or imprisonment to break cultural norms and pursue interracial relationships (Crowder \& Tolnay, 2000; Raley \& Sullivan, 2010). 


\subsection{Limitations}

Despite the contributions of the study, limitations must be noted. This study intentionally oversampled drug users and individuals with different types of involvement in the criminal justice system; thus, it is not representative of African American women as a whole.

Nevertheless, examining the interracial dating intentions and behaviors of African American women with multiple disadvantaged statuses (e.g., those with low-income, are drug-using, or have been involved in the criminal justice system) makes an important contribution to the literature as these women may have an even smaller pool of potential eligible African American male partners than a general population of African American women. There is currently a call for more within-group research (Knight, Roosa, \& Umaña-Taylor, 2009). Thus, it is imperative to examine within-racial group variation in interracial dating intentions and behaviors as all African American women do not have the same amount of social capital or bargaining power in romantic relationships.

As secondary cross-sectional data, this study was limited to existing measures included in the dataset and only associations could be examined. For example, items were limited to African American women's perspective even though potential partner's racial preference plays a large role in interracial dating. Additional measures which may be relevant (e.g., family or friend acceptance of interracial relationships and contact with people of other races) were not included in the dataset. Further research in this area using qualitative data or longitudinal data would provide more insight into African American women's interracial relationship intentions and behaviors. In addition, future research should also explore the dating behaviors of women within their structural setting using multilevel modeling; this method is better suited to address the importance of contextual factors such as a woman who desires to date outside of her race but lives in a highly segregated and racially homogenous neighborhood. Finally, it should be noted that African American women's interracial relationships come in more combinations than black/white or black/Hispanic. Due to the relatively small populations of other racial groups in the region, this survey did not ask questions about, for example, Asians or American Indians. However, future research should not be similarly restricted and can explore a larger constellation of interracial relationship intentions and behaviors as well as examine African American men's interracial dating intentions and behaviors.

\subsection{Conclusions}

This study makes a contribution to the literature by exploring the relationship between African American women's perceptions about partner availability and both interracial dating intentions and behavior with white and Hispanic men, during time when many present-day scholars (Alexander, 2010; Crowder \& Tolnay, 2000; Wolfers, Leonhardt, \& Quealy, 2015) have noted the trend of a depleted pool of African American male partners as outlined by the MMPI (Wilson, 1987). This study indicates that African American women who believe it is easier to find an eligible man outside their race are more likely to have interracial relationship intentions; however, cultural mistrust impedes African American women's willingness to date someone who is white or Hispanic. The strong relationship between intentions and behaviors in the multivariate models in this study suggests the efforts by 
whites to answer in a dishonest, yet socially desirable way identified by Bonilla-Silva (2001) were not common among African American women.

Studying interracial relationship intentions and behaviors in a predominantly disadvantaged sample of African American women, who are among the least likely to marry interracially, also informs our understanding of the social distance between racial groups in the United States (Bogardus, 1933). Based on this study, the social distance (particularly between African Americans and whites) may be shrinking and it is possible that the male marriageable pools for African American women may be broadening to include men of other races/ethnicities. Additionally, the social distance maintained between racial groups, as indicated by rates of interracial relationships, appears to be primarily related to the preferences of men to not date African American women. While the interracial relationship intentions of African American women were relatively high, there may be a bias against economically disadvantaged African American women by white and Hispanic men in the dating pool.

\section{Acknowledgements}

This research is funded by the National Institute on Drug Abuse (R01-DA022967, PI: Oser; K02-DA35116, PI: Oser). This research would not have been possible without the Kentucky Department of Corrections participation. Neither NIDA nor the Kentucky Department of Corrections had a role in the study design, data collection, analyses, interpretation, writing, or decision to submit the manuscript for publication. We appreciate the women who shared their stories and want to acknowledge the contribution of the interviewers and community partners.

\section{References}

Ajzen I. The theory of planned behavior. Organizational Behavior and Human Decision Processes. 1991; 50:179-211.

Alexander, M. The new Jim Crow: Mass incarceration in the age of colorblindness. The New Press; New York: 2010.

Banks, RR. Is marriage for white people? How the African American marriage decline affects everyone. Dutton; New York: 2011.

Barnes PW, Lightsey OR Jr. Perceived racist discrimination, coping, stress, and life satisfaction. Journal of Multicultural Counseling and Development. 2005; 33(1):48-61.

Bennett NG, Bloom DE, Craig PH. The divergence of Black and White marriage patterns. American Journal of Sociology. 1989; 95:692-722.

Bogardus ES. A social distance scale. Sociology and Social Research. 1933; 17:265-271.

Bond S, Cash TF. Black beauty: Skin color and body images among African American college women. Journal of Applied Social Psychology. 1992; 22:874-888.

Bonilla-Silva, E. White supremacy and racism in the post-civil rights era. Lynne Rienner Publishers; Boulder: 2001.

Bratter JL, Eschbach K. 'What about the couple?' Interracial marriage and psychological distress. Social Science Research. 2006; 35:1025-1047.

Childs EC. Looking behind the stereotypes of the "angry Black woman": An exploration of Black women's responses to interracial relationships. Gender \& Society. 2005; 19:544-561.

Clarke, AY. Inequalities of love: College-educated black women and the barriers to romance and family. Duke University Press; Durham, NC: 2011.

Collins, PH. Black feminist thought: Knowledge, consciousness, and the politics of empowerment. 2nd Edition. Routledge; New York: 1999.

Crowder KD, Tolnay SE. A new marriage squeeze for Black women: The role of racial intermarriage by Black men. Journal of Marriage and the Family. 2000; 62:792-807.

Soc Sci Res. Author manuscript; available in PMC 2016 September 01. 
Dougherty KD, Huyser KR. Racially diverse congregations: Organizational identity and the accommodation of differences. Journal for the Scientific Study of Religion. 2008; 47:23-43.

Feagin, JR. Racist America: Roots, current realities, and future reparations. 3rd edition. Routledge; New York: 2014.

Feagin, JR.; Vera, H.; Batur, P. White racism. 2nd edition. Routledge; New York: 2000.

Feliciano C, Robnett B, Komaie G. Gendered racial exclusion among white internet daters. Social Science Research. 2009; 38:41-56.

Golebiowska EA. The contours and etiology of Whites' attitudes toward Black-White interracial marriage. Journal of Black Studies. 2007; 38:268-287.

Gullickson A. Black/White interracial marriage trends, 1850-2000. Journal of Family History. 2006; 31:289-312.

Guzzo K. How do marriage market conditions affect entrance into cohabitation vs. marriage? Social Science Research. 2006; 35(2):332-355.

Harris DR, Ono H. How many interracial marriages would there be if all groups were of equal size in all places? A new look at national estimates of interracial marriage. Social Science Research. 2005; 34:236-251.

Heaton TB, Jacobson CK. Intergroup marriage: An examination of opportunity structures. Sociological Inquiry. 2000; 70:30-41. [PubMed: 17642119]

Heer DM. The prevalence of Black-White marriage in the United States, 1960 and 1970. Journal of Marriage and Family. 1974; 36(2):246-258.

Jacobson CK, Johnson BR. Interracial friendship and African American attitudes about interracial marriage. Journal of Black Studies. 2006; 36:570-584.

Janoski, T.; Luke, D.; Oliver, C. The causes of structural unemployment: Four factors that keep people from the jobs they deserve. Polity Press; London: 2014.

Johnson BR, Jacobson CK. Contact in context: An examination of social settings on Whites' attitudes toward interracial marriage.”. Social Psychology Quarterly. 2005; 68:387-399.

Knight, GP.; Roosa, MW.; Umaña-Taylor, AJ. Methodological challenges in studying ethnic minority or economically disadvantaged populations. American Psychological Association; Washington, DC: 2009.

Kroeger RA, Williams K. Consequences of Black exceptionalism? Interracial unions with Blacks, depressive symptoms, and relationship satisfaction. Sociological Quarterly. 2011; 52:400-420. [PubMed: 22081799]

Landrine H, Klonoff EA. The schedule of racist events: A measure of racial discrimination and a study of its negative physical and mental health consequences. Journal of Black Psychology. 1996; 22:144-68.

Laumann E, Youm Y. Racial/ethnic group differences in the prevalence of sexually transmitted diseases in the United States: A network explanation. Sexually Transmitted Diseases. 1999; 26:250-261. [PubMed: 10333277]

Lewis R, Ford-Robertson J. Understanding the occurrence of interracial marriage in the United States through differential assimilation. Journal of Black Studies. 2010; 41:405-420. [PubMed: 21174875]

Luke, DJ. Multiracial churches: An unusual arrangement. Theses and Dissertations--Sociology. 2012. Paper 5. http://uknowledge.uky.edu/sociology_etds/5

Maddox KB. Perspectives on racial phenotypicality bias. Personality and Social Psychology Review. 2004; 8:383-401. [PubMed: 15582860]

Massey, DS.; Denton, NA. American apartheid: Segregation and the making of the underclass. Harvard University Press; Cambridge, MA: 1993.

Mead, GH. Mind, Self, and Society. University of Chicago Press; Chicago: 1934.

Newsome V, Airhihenbuwa C. Gender ratio imbalance effects on HIV risk behaviors in African American women. Health Promotion Practice. 2013; 14:459-463. [PubMed: 23041754]

Oser C, Pullen E, Stevens-Watkins D, Perry B, Havens J, Staton-Tindall M, Leukefeld C. Intimate partnter characteristics: Understanding their association with sexually transmitted infections among African American females. Manuscript under review. 2015

Soc Sci Res. Author manuscript; available in PMC 2016 September 01. 
Owen CA, Eisner HC, McFaul TR. A half-century of social distance research - national replication of the Bogardus studies. Sociology and Social Research. 66(1):80-98.

Pagnini DL, Morgan SP. Intermarriage and social distance among United States immigrants at the turn-of-the-century. American Journal of Sociology. 1990; 96(2):405-432.

Qian ZC, Lichter DT. "Measuring marital assimilation: Intermarriage among natives and immigrants.". Social Science Research. 2001; 30:289-312.

Qian ZC, Lichter DT. Social boundaries and marital assimilation: Interpreting trends in racial and ethnic intermarriage. American Sociological Review. 2007; 72:68-94.

Quillian L, Campbell ME. Beyond Black and White: The present and future of multiracial friendship segregation. American Sociological Review. 2003; 68:540-566.

Raley RK, Sullivan MK. Social-contextual influences on adolescent romantic involvement: The constraints of being a numerical minority. Sociological Spectrum. 2010; 30:65-89. [PubMed: 20161469]

Russell, K.; Wilson, M.; Hall, R. The color complex: The politics of skin color among African Americans. Anchor Books; New York: 1993.

Schneider, Daniel. Wealth and the marital divide. American Journal of Sociology. 2011; 117(2):627667.

Staples, R. The world of Black singles: Changing patterns of male/female relations. Greenwood Press; Westport, CT: 1981.

Staton-Tindall M, Leukefeld C, Palmer J, Oser C, Kaplan A, Krietemeyer J, Saum C, Surratt H. Relationships and HIV risk among incarcerated women. The Prison Journal. 2007; 87:143-165.

Terrell, F.; Terrell, S. The cultural mistrust inventory: Development, findings and implications. In: Jones, RL., editor. Handbook of tests and measurements for black populations. Cobb \& Henry Publishers; Hampton, VA: 1996. p. 321-331.

Thomas JC, Thomas KK. Things ain't what they ought to be: Social forces underlying racial disparities in rates of sexually transmitted diseases in a rural North Carolina county. Social Science \& Medicine. 1999; 49:1075-84. [PubMed: 10475671]

Wilson, WJ. The truly disadvantaged: The inner city, the underclass, and public policy. The University of Chicago Press; Chicago: 1987.

Wolfers, J.; Leonhardt, D.; Quealy, K. [Accessed April 23, 2015] The Upshot: 1.5 Million Missing Black Men. The New York Times. Apr 20. 2015 Available at http://nyti.ms/1P5Gpa7

Yancey G. Crossracial differences in the racial preferences of potential dating partners: A test of the alienation of African Americans and social dominance orientation. Sociological Quarterly. 2009; 50:121-143.

U.S. Census Bureau. Sex by marital status for the population age 15 years and over (Black or African American alone). U.S. Census Bureau, 2005 Community Survey; Washington, DC: 2005. Available at http://factfinder2.census.gov/faces/tableservices/jsf/pages/productview.xhtml?pi d=ACS_05_EST_B12002B\&prodType=table [Accessed June 5, 2013]

U.S. Census Bureau. Sex by marital status for the population age 15 years and over (Black or African American alone). U.S. Census Bureau, 2011 Community Survey; Washington, DC: 2011. Available at http://factfinder2.census.gov/faces/tableservices/jsf/pages/productview.xhtml? pid=ACS_11_1YR_B12002B\&prodType=table [Accessed June 5, 2013]

U.S. Census Bureau. Male-female ratio by sex alone or in combination and Hispanic or Latino origin for the United States: 2000. U.S. Census Bureau, Census 2000 Summary; Washington, DC: 2000. File 1. Available at www.census.gov/population/cen2000/phct11/tab01.pdf [Accessed July 1, 2005] 


\section{Table 1}

\section{Descriptive Statistics of African American Women}

\begin{tabular}{|c|c|c|c|}
\hline Variables & Proportion & $\mathbf{M}$ & SD \\
\hline Would date someone white & 0.70 & - & - \\
\hline Would date someone Hispanic & 0.43 & & \\
\hline Has dated someone white & 0.56 & - & - \\
\hline Has dated someone Hispanic & 0.17 & & \\
\hline \multicolumn{4}{|l|}{ Criminal justice system status } \\
\hline Prison & 0.36 & - & - \\
\hline Probation & 0.31 & - & - \\
\hline Community & 0.33 & - & - \\
\hline Age & & 36.02 & 11.53 \\
\hline Household income (in tens of thousands USD) & & 1.78 & 1.82 \\
\hline Number of years of education & - & 12.06 & 2.16 \\
\hline Self-identified light skin tone ${ }^{a}$ & 0.20 & & \\
\hline Drug use (past year) & 0.61 & - & - \\
\hline Cultural mistrust & & 45.66 & 10.85 \\
\hline Racist life events & - & 31.86 & 13.72 \\
\hline Difficult to find African American man & 0.46 & - & - \\
\hline Easier to find eligible white man & 0.26 & - & - \\
\hline Easier to find eligible Hispanic man & 0.18 & & \\
\hline
\end{tabular}




\section{로을}

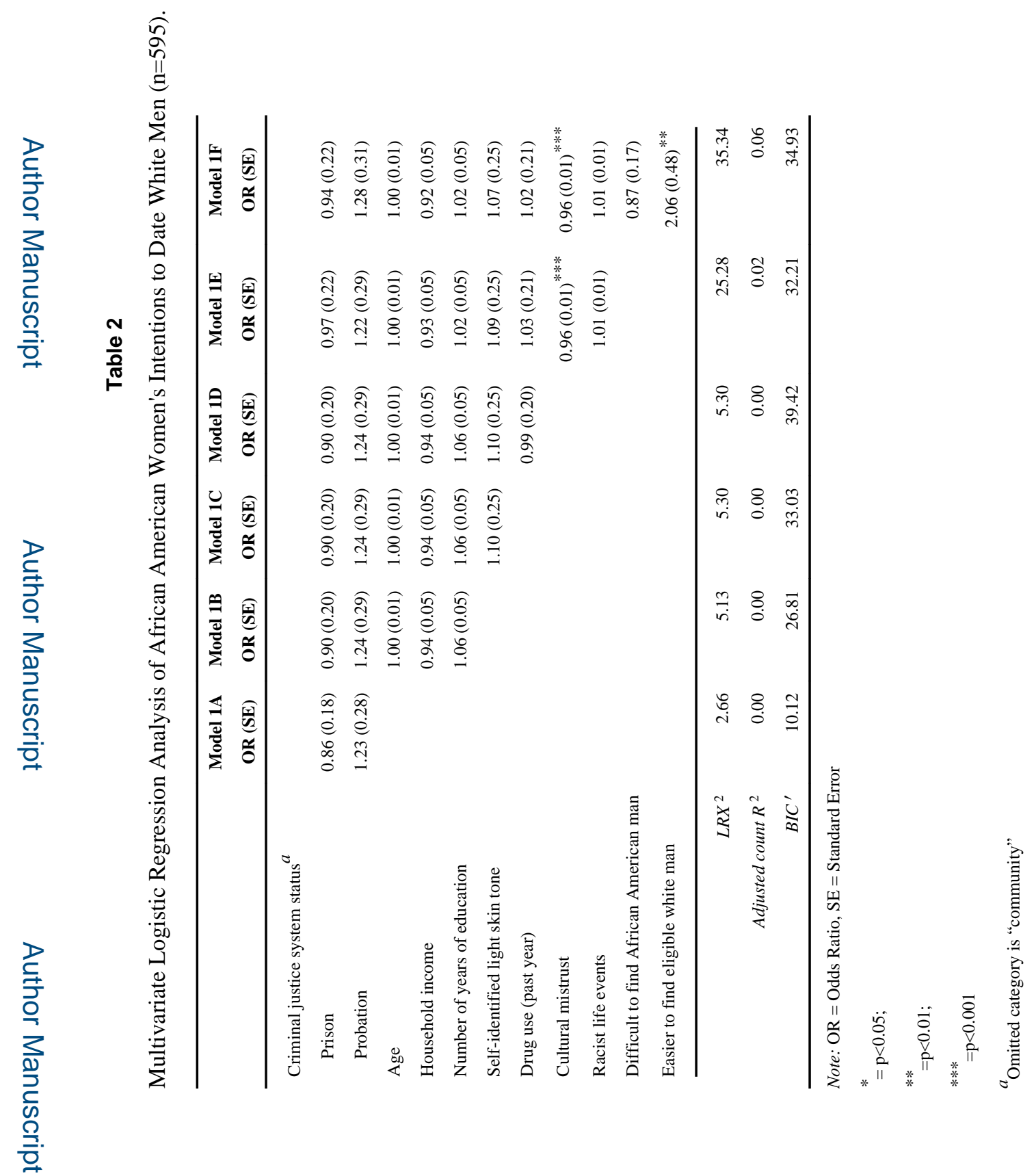
Soc Sci Res. Author manuscript; available in PMC 2016 September 01. 
Table 3

Predicted Probability of Whether Respondent Would Date Someone White Based on Her Perception of the Availability of White Male Partners and Her Level of Cultural Mistrust (the Mean +/- One Standard Deviation)

\begin{tabular}{lccc}
\hline & Low & Cultural Mistrust Medium & High \\
\hline Not easier to find white man & $0.77(0.71-0.82)$ & $0.67(0.63-0.72)$ & $0.56(0.49-0.63)$ \\
Easier to find white man & $0.87(0.82-0.93)$ & $0.81(0.75-0.87)$ & $0.73(0.64-0.81)$ \\
\hline
\end{tabular}

Note: Predicted probabilities are presented, confidence intervals in parentheses 


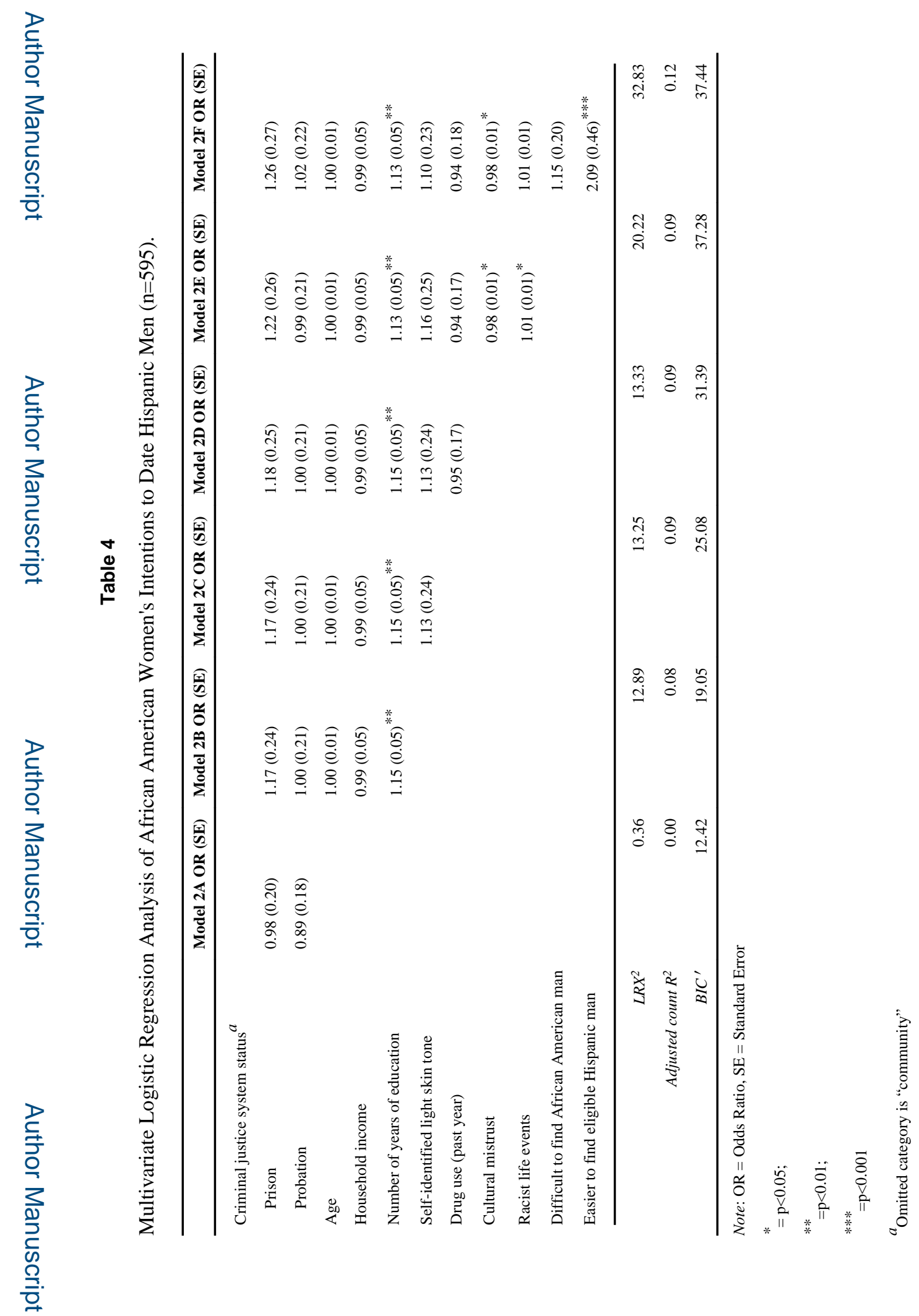




\section{Table 5}

Predicted Probability of Whether Respondent Would Date Someone Hispanic Based on Her Perception of the Availability of Hispanic Male Partners and Her Level of Cultural Mistrust (the Mean +/- One Standard Deviation)

\begin{tabular}{lccc}
\hline & Low & Cultural Mistrust Medium & High \\
\hline Not easier to find Hispanic man & $0.45(0.38-0.51)$ & $0.39(0.35-0.44)$ & $0.34(0.28-0.41)$ \\
Easier to find Hispanic man & $0.63(0.52-0.73)$ & $0.57(0.48-0.67)$ & $0.52(0.42-0.63)$ \\
\hline
\end{tabular}

Note: Predicted probabilities are presented, confidence intervals in parentheses 


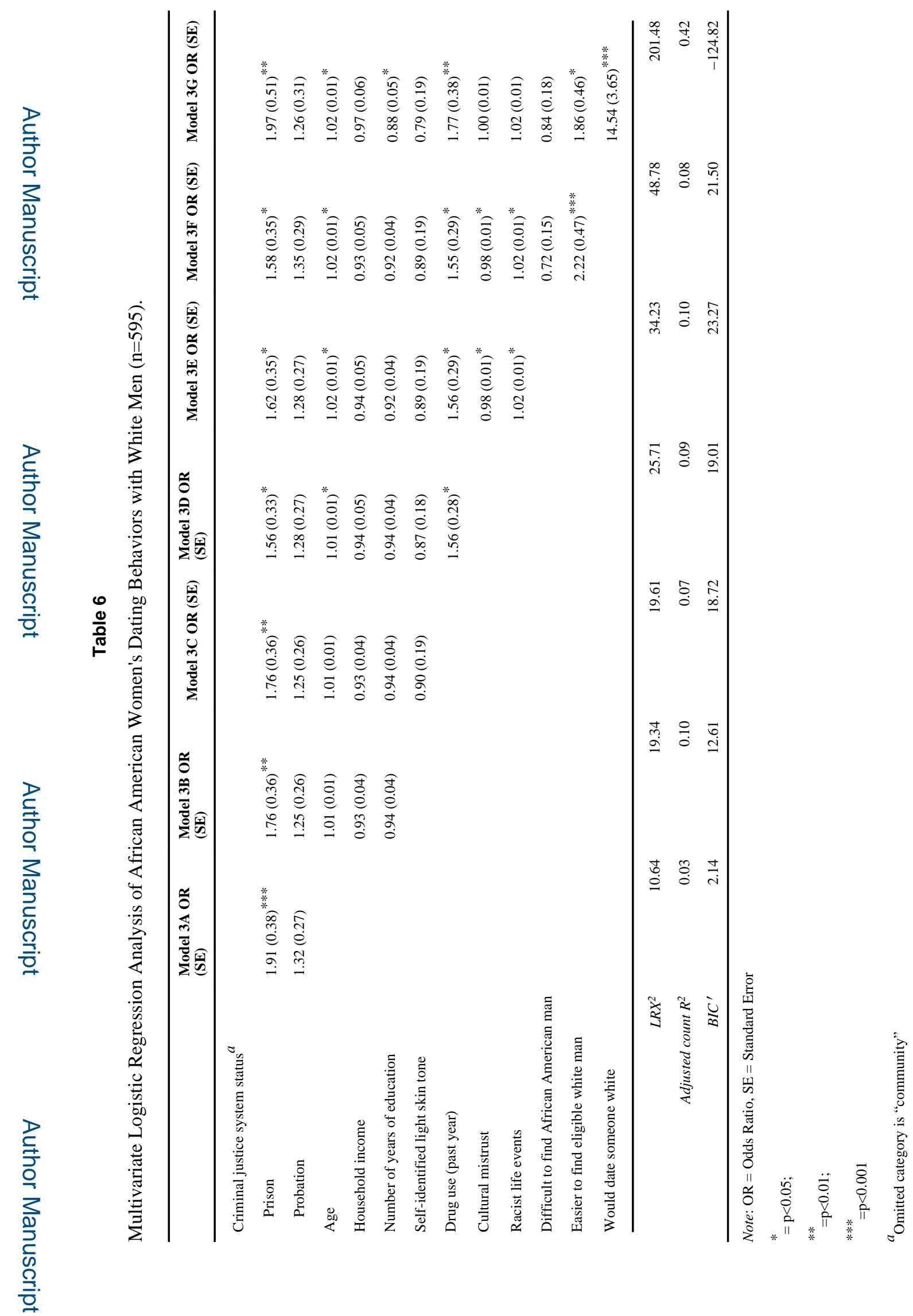

Soc Sci Res. Author manuscript; available in PMC 2016 September 01. 


\section{Table 7}

Predicted Probability Respondent Has Ever Dated Someone White Based on Whether Respondent Stated She Would Date Someone White, Respondent's Years of Education (Mean +/- One Standard Deviation), and Perception of the Availability of White Male Partners

\begin{tabular}{lcc}
\hline & \multicolumn{2}{c}{ Easier to find eligible white man } \\
& Easier & Not easier \\
\hline Low education & & \\
Would date white & $0.86(0.79-0.92)$ & $0.76(0.70-0.83)$ \\
Would not date white & $0.29(0.17-0.41)$ & $0.18(0.11-0.25)$ \\
Mean education & & \\
Would date white & $0.82(0.75-0.88)$ & $0.71(0.65-0.76)$ \\
Would not date white & $0.24(0.14-0.34)$ & $0.14(0.09-0.20)$ \\
High education & & \\
Would date white & $0.77(0.69-0.86)$ & $0.65(0.57-0.72)$ \\
Would not date white & $0.19(0.10-0.28)$ & $0.11(0.06-0.16)$ \\
\hline
\end{tabular}

Note: Predicted probabilities are presented, confidence intervals in parentheses 


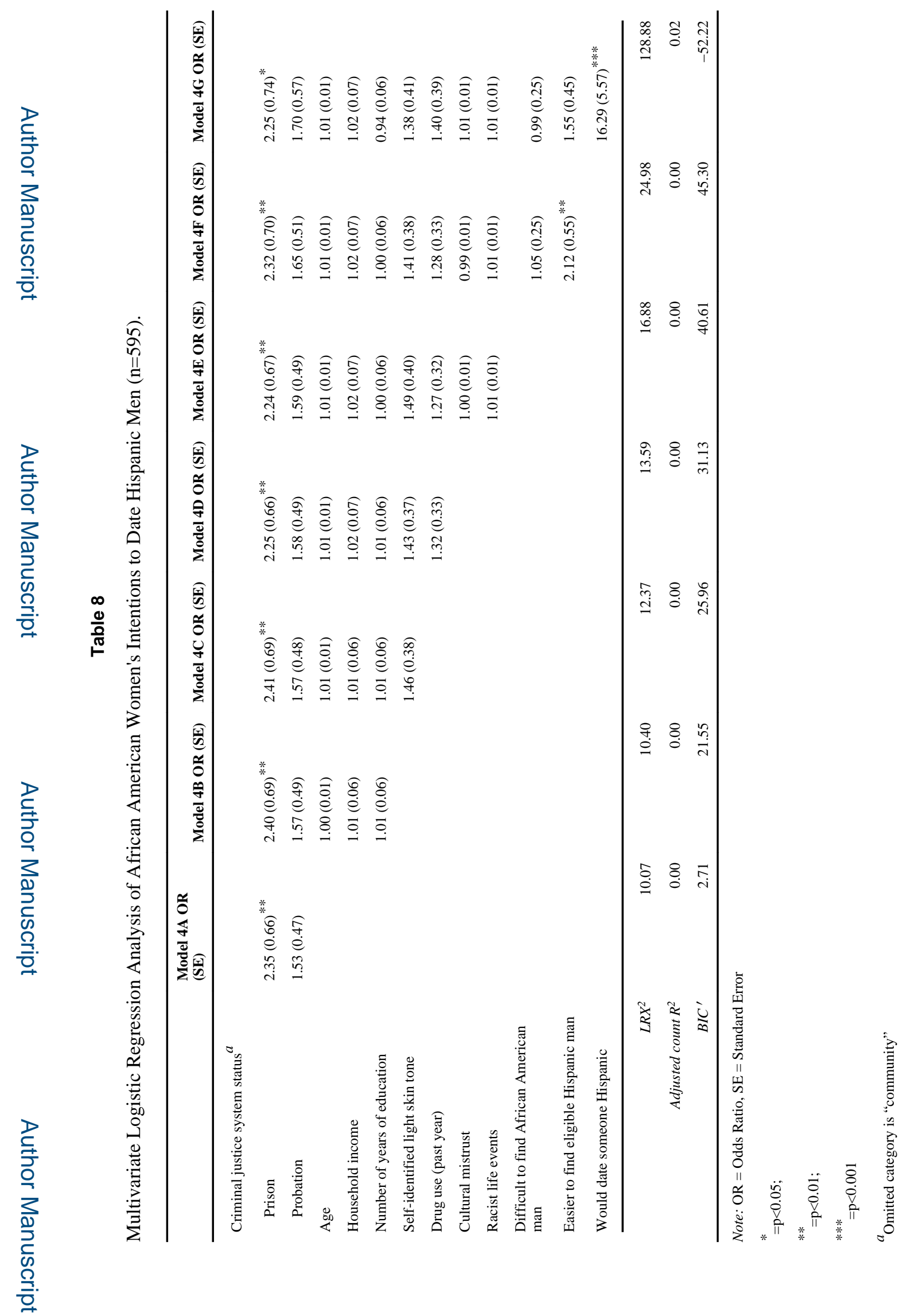

Soc Sci Res. Author manuscript; available in PMC 2016 September 01. 


\section{Table 9}

Predicted Probability Respondent Has Ever Dated Someone Hispanic Based on Whether Respondent Stated She Would Date Someone Hispanic, Respondent's Years of Education (Mean +/- One Standard Deviation), and Her Perception of the Availability of Hispanic Male Partners

\begin{tabular}{lcc}
\hline & Easier to find eligible Easier & Hispanic man Not easier \\
\hline Low education & $0.44(0.30-0.59)$ & $0.34(0.25-0.44)$ \\
$\quad$ Would date Hispanic & $0.05(0.01-0.08)$ & $0.03(0.01-0.05)$ \\
$\quad$ Would not date Hispanic & & \\
Mean education & $0.41(0.29-0.53)$ & $0.31(0.25-0.38)$ \\
$\quad$ Would date Hispanic & $0.04(0.01-0.07)$ & $0.03(0.01-0.04)$ \\
$\quad$ Would not date Hispanic & & \\
High education & $0.38(0.25-0.51)$ & $0.29(0.21-0.37)$ \\
$\quad$ Would date Hispanic & $0.04(0.01-0.07)$ & $0.02(0.01-0.04)$ \\
$\quad$ Would not date Hispanic &
\end{tabular}

Note: Predicted probabilities are presented, confidence intervals in parentheses 